\title{
Copper induces cellular senescence in human glioblastoma multiforme cells through downregulation of Bmi-1
}

\author{
YUAN LI ${ }^{1,2^{*}}$, JIFAN HU $^{2 *}$, FANGXIA GUAN ${ }^{3}$, LAIJUN SONG $^{1}$, RUITAI FAN ${ }^{4}$, \\ HUAIJIE $\mathrm{ZHU}^{5}$, XIANG HU ${ }^{6}$, EILEEN SHEN ${ }^{7}$ and BO YANG ${ }^{1}$ \\ ${ }^{1}$ Department of Neurosurgery, The First Affiliated Hospital of Zhengzhou University, Zhengzhou, Henan 450052, \\ P.R. China; ${ }^{2}$ VA Palo Alto Health Care System, Stanford University School, Palo Alto, CA 94304, USA; \\ ${ }^{3}$ Department of Bioengineering, Zhengzhou University, Zhengzhou, Henan 450001; ${ }^{4}$ Radiotherapy Center, \\ The First Affiliated Hospital of Zhengzhou University, Zhengzhou, Henan 450052, P.R. China; \\ ${ }^{5}$ Department of Pathology and Cell Biology, Columbia University, New York, NY 10032, USA; \\ ${ }^{6}$ Shenzhen Beike Cell Engineering Institute, Shenzhen, Guangdong 518057, P.R. China; ${ }^{7}$ Division \\ of Molecular Biology and Biochemistry, Dickinson College, Carlisle, PA 17013, USA
}

Received November 13, 2012; Accepted January 9, 2013

DOI: $10.3892 /$ or.2013.2333

\begin{abstract}
Most human tumor cells, including glioblastoma multiforme (GBM) cells, have aberrant control of cell aging and apoptosis. Subcytotoxic concentrations of oxidative or stress-causing agents, such as hydrogen peroxide, may induce human cell senescence. Thus, induction of tumor cells into premature senescence may provide a useful in vitro model for developing novel therapeutic strategy to combat tumors. In the present study, we assessed the molecular mechanism(s) underlying senescence in GBM cells induced by copper sulfate. Following pretreatment with subcytotoxic concentrations of copper sulfate, U87-MG tumor cells showed typical aging characteristics, including reduced cell proliferation, cell enlargement, increased level of senescence-associated $\beta$-galactosidase (SA $\beta$-gal) activity, and overexpression of several senescence-associated genes, p16, p21, transforming growth factor $\beta-1$ (TGF- $\beta 1$ ), insulin growth factor binding protein 3 (IGFBP3) and apolipoprotein $\mathbf{J}$ (ApoJ). We further demonstrated that the Bmi-1 pathway was downregulated in GBM cells in parallel with the induced senescence. The present study for the first time demonstrates the ability of copper to induce GBM cell senescence by downregulating Bmi-1.
\end{abstract}

Correspondence to: Professor Bo Yang, Department of Neurosurgery, The First Affiliated Hospital of Zhengzhou University, 1 Jianshe Road, Zhengzhou, Henan 450052, P.R. China

E-mail: yangbo96@yahoo.com

Dr Fangxia Guan, Department of Bioengineering, Zhengzhou University, Zhengzhou, Henan 450001, P.R. China

E-mail: guanfx@zzu.edu.cn

*Contributed equally

Key words: glioblastoma, copper metal, senescence, Bmi-1

\section{Introduction}

Glioblastoma multiforme (GBM) is one of the most prevalent and aggressive malignant primary brain tumor in adult patients, usually with poor prognosis and a low 5-year survival rate $(1,2)$. During the past two decades, many advances had been made to GBM treatment, including new neurosurgerical techniques, radiation therapy and novel chemotherapeutics, yet the patient survival time from initial diagnosis has not significantly increased; the vast majority of patients succumb to the disease within 2 years (3-6). Thus, the development of new therapeutic strategies specifically targeting the apoptotic or senescence pathway which may improve treatment responses has become the focus of antitumor research.

Unlike normal brain cells, glioblastoma cells exhibit certain stem cell-like features, such as self-renewal ability, unlimited proliferation, differentiation capacity, and repressed premature senescence and apoptosis. Consequently, the induction of glioblastoma cells into a senescent state may be effective as a novel therapeutic strategy. Several critical regulatory genes associated with apoptotic and senescence have been identified in human glioblastoma. These genes mainly promote tumor growth, invasion and resistance to conventional chemotherapy and radiotherapy (1,7-9).

Cellular senescence is a normal physiological process characterized by a decrease in the number of dividing cells, unresponsiveness to mitogenic stimuli that finally triggers self-apoptosis. Compared with proliferating cells, cells entering into a senescence state undergo dramatic structural alterations, such as a decrease in mass, and a change in the function of subcellular organelles, and in particular exhibit enlarged flat morphology, reactive oxygen production, lipofuscin accumulation, and enhanced activity of senescenceassociated $\beta$-galactosidase (SA $\beta$-gal), and alter the expression of several senescence-associated genes $(10,11)$ such as p16, p21, transforming growth factor $\beta-1$ (TGF- $\beta 1$ ), insulin growth 
factor binding protein 3 (IGFBP3) and apolipoprotein $\mathrm{J}$ (ApoJ). Particularly in stem cells, Bmi-1 is a critical gene that controls self-renewal.

Copper functions as a co-factor of different enzymes in cellular metabolism, such as cytochrome $c$ oxidase and $\mathrm{Cu} / \mathrm{Zn}$ superoxide dismutase (12). In contrast, cellular ionic copper in excess damages different types of biomolecules through cytotoxicity and by mediating the generation of the highly reactive hydroxyl radical $(13,14)$. Thus, copper is an essential trace element for the process of cellular senescence due to its dual role in the biological system. In many ageassociated disorders such as Alzheimer's and Parkinson's disease, excess accumulation of copper is a crucial factor in pathogenesis $(15,16)$.

In the present study, we investigated the alterations in cell morphology and molecular genesis of the glioblastoma cell line U87-MG following exposure to subcytotoxic doses of copper sulfate. We demonstrated that copper sulfate induces glioblastoma cell lines into a replicative senescent state, and we further verified a change in the expression of senescence-associated genes and confirmed copper exposure-induced senescence through the Bmi-1 pathway.

\section{Materials and methods}

Cell culture and proliferation. U87-MG glioma cell lines were obtained from the American Type Culture Collection and were routinely cultured in a $10-\mathrm{cm}$ culture dish containing $10 \mathrm{ml}$ Minimum Essential Medium (MEM), $\alpha$-modified MEM, supplemented with $10 \%$ fetal bovine serum (FBS), $1 \%$ non-essential amino acid (NEAA), $1 \%$ glutamine and $1 \%$ antibiotics (penicillin-streptomycin) at $37^{\circ} \mathrm{C}$ in an atmosphere containing $5 \% \mathrm{CO}_{2}$. Cells were subcultured into 3 new dishes when confluent.

Copper cytotoxicity. The cell survival rate was measured after cells were exposed to 5 different doses of copper sulfate $(0,100,250,500$ and $750 \mu \mathrm{M})$ to optimize copper cytotoxicity based on a previous report (17), and was compared with the controls (750 $\mu \mathrm{M} \mathrm{Na} \mathrm{SO}_{4}$ ). We replaced the new whole medium without copper sulfate after a 24-h exposure, and then added neutral red staining dye $(40 \mu \mathrm{g} / \mathrm{ml})$, and continued the incubation for $3 \mathrm{~h}$ at $37^{\circ} \mathrm{C}$. Cells were washed with DPBS after staining, lysised with acetic acid (1\% v/v) and dissolved in $50 \%(\mathrm{v} / \mathrm{v})$ ethanol. The optical absorbance was recorded by a microplate reader (GeneAmp 5700 Sequence Detector) at $540 \mathrm{~nm}$. The cells treated with sodium sulfate were set as the control.

Cell proliferation assay. The effect of copper exposure on the proliferation of the U87-MG cells was assessed by MTT assay. MTT assay is a classical method used for cell density determination, by testing activity of dehydrogenase enzymes. Cells $\left(2 \times 10^{4} /\right.$ well) were plated onto 96-well plates. After cells attached, different doses of copper sulfate were added into the supernatants, and then fixed with MTT at different time-points (1, 2, 3 and 4 days) After MTT fixation for $4 \mathrm{~h}$ at $37^{\circ} \mathrm{C}$, the supernatant was discarded and the sediment was dissolved with $150 \mu \mathrm{l}$ DMSO. Then, the absorbance at $570 \mathrm{~nm}$ for each well was recorded using a microplate reader (GeneAmp 5700
Sequence Detector). Growth curves were constructed according to the collected data.

Senescence-associated $\beta$-galactosidase. After a 24-h copper exposure in 6-well plates, the supernatant was discarded including the ionic copper, and the cells were washed with DPBS twice. Whole medium was added and culture was continued for another $48 \mathrm{~h}$. After culture, the activity of senescence-associated $\beta$-galactosidase (SA $\beta$-gal) was determined as described by Dimri et al (18). The proportion of SA $\beta$-gal-positive cells was determined by counting 400 cells/well under a microscope.

Real-time PCR analysis. RNA was extracted by TRIzol reagent (Sigma) from cells after 3 days of exposure to copper. Total RNA ( $2 \mu \mathrm{g})$ was converted to cDNA by reverse transcription reaction. Real-time polymerase chain reaction (PCR) was employed using 1X Express SYBR-Green ER (Invitrogen), primers (10 pM) and an optimal concentration of cDNA (4 ng) as follows: hot start at $95^{\circ} \mathrm{C}$ for $10 \mathrm{~min}$, followed by $95^{\circ} \mathrm{C}$ for $15 \mathrm{sec}, 60^{\circ} \mathrm{C}$ for $1 \mathrm{~min}$ for 40 cycles, and $9^{\circ} \mathrm{C}$ for $15 \mathrm{sec}, 60^{\circ} \mathrm{C}$ for $15 \mathrm{sec}$. We designed the primers as follows: apolipoprotein J-F, GGA TGA AGG ACC AGT GTG ACA AG and apolipoprotein J-R, CAG CGA CCT GGA GGG ATT C; TGF- $\beta 1-F$, AGG GCT ACC ATG CCA ACT TCT and TGF- $\beta 1-R$, CCG GGT TAT GCT GGT TGTACA; p21-F, CTG GAG ACT CTC AGG GTC GAA and p21-R, CCA GGA CTG CAG GCT TCC T; IGFBP3-F, CAG AGC ACA GAT ACC CAG AAC TTC and IGFBP3-R, CAC ATT GAG GAA CTT CAG GTG ATT; p16-F, CTA CTG AGG AGC CAG CGT CTA GG and p16-R, AGA GTG GCG GGG TCG GCG CAG TT; Bmi-1-F, GAG ATC GGG GCG AGA CAA TG and Bmi-1-R, GAC CTC CAA CGC CTC CTC CT; actin-F, CAG GTC ATC ACC ATT GGC AAT GAG C and actin-R, CGG ATG TCC ACG TCA CAC TTC ATG A. The specificity of amplification was checked by performing melting curves and electrophoresis of the amplification products.

Western blot analysis. Treated U87-MG cells were washed with ice-cold DPBS twice, and then replaced with $1 \mathrm{ml}$ $0.25 \%$ trypsin, and incubated for $5 \mathrm{~min}$ at $37^{\circ} \mathrm{C}$. The cells were collected into $2-\mathrm{ml}$ tubes and spun down for $15 \mathrm{~min}$ at $2,500 \mathrm{rpm}$ at $4^{\circ} \mathrm{C}$. The pellet was lysed with $100 \mu \mathrm{l}$ RIPA buffer $\left(10 \mathrm{mM} \mathrm{NaPO}_{4}, \mathrm{pH} 7.2,0.3 \mathrm{M} \mathrm{NaCl}, 0.1 \%\right.$ SDS, $1 \%$ NP40, $1 \%$ deoxycholate, $2 \mathrm{mM}$ EDTA) on ice for at least $30 \mathrm{~min}$. The titer of the protein extracts was quantified by Bradford assay (19). An equal amount of protein $(50 \mu \mathrm{g} /$ lane) was loaded on SDS-PAGE gels for electrophoresis. After appropriate separation, proteins were transferred to a nitrocellulose membrane, and then blocking with $5 \%$ non-fat dry milk diluted in Tris buffer saline $0.1 \mathrm{M}$ added to $0.1 \%$ Tween-20 (TBST). Proteins were coated with special monoclonal primary antibodies against Bmi-1, p16 and p21 (Abcam, Cambridge, MA, USA) and actin (Santa Cruz Biotechnology, Santa Cruz, CA, USA) overnight at $4^{\circ} \mathrm{C}$. After washing with TBST for 3 times, a peroxidase-conjugated secondary antibody was added to detect the proteins at room temperature for $1 \mathrm{~h}$. Immunoblots were detected by ECL Western Blotting Kit (Pierce ${ }^{\mathrm{TM}}-$ Thermo Scientific). Results were recorded by exposure to X-ray film. Actin was detected as the control. 


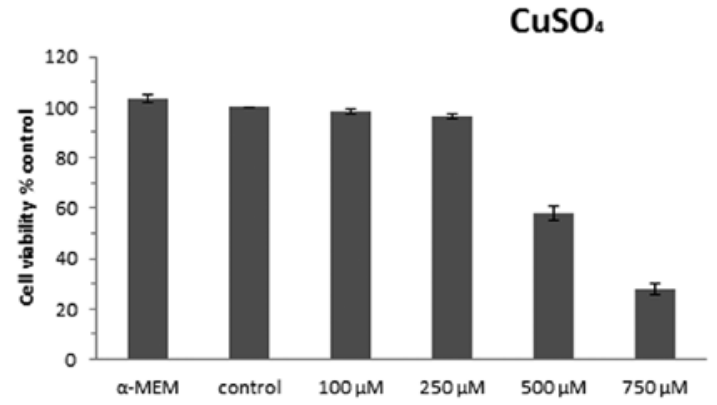

Figure 1. Cell viability after a 24 -h exposure to different doses of copper sulfate. With increasing concentrations of copper sulfate, the cell viability was accordingly decreased. The control group treated with $750 \mu \mathrm{M} \mathrm{NaSO}_{4}$ for $24 \mathrm{~h}$, was assumed to exhibit $100 \%$ viability and did not show a significant difference in cell viability when compared with cells cultured in whole medium ( $\alpha$-MEM). Cell viability was copper sulfate dose-dependent from 100 to $750 \mu \mathrm{M}$. However, subcytotoxic doses of 100 and $250 \mu \mathrm{M}$ led to a slight decrease in cell viability to 98.2 and $94.6 \%$, while cells exposed to higher doses of copper sulfate, 500 and $750 \mu \mathrm{M}$, resulted in a marked decrease in cell viability to 58.0 and $28.1 \%$, respectively.

Statistical analysis. The t-test was performed to compare normal and senescent states. $\mathrm{P}<0.05$ was considered to indicate a statistically significant difference.

\section{Results}

Effect of copper sulfate on cellular viability. In order to determine the optimal appropriate subcytotoxic concentration of copper sulfate, we used 5 different concentrations of copper sulfate: $0,100,250,500$ and $750 \mu \mathrm{M}$ for $24 \mathrm{~h}$ based on previous research (17), and we determined the mean cell viability from three independent experiments, setting the control cells as $100 \%$. Cell viability was assessed using neutral red assay as shown in Fig. 1. The control cells did not have significant differences in viability when compared with cells cultured in $\alpha$-MEM medium (103.3\%). The doses of copper sulfate used and the viability of the U87-MG cells were found to have a dose-effect relationship; the viability of the cells decreased according to the increasing doses of copper sulfate used. When the cells were exposed to 100 and $250 \mu \mathrm{M}$ copper sulfate, the cell viability was found to be 98.2 and $96.4 \%$ compared with the control cells, indicating that no significant differences in cell viability were observed. The viability of the cells exposed to 500 and $750 \mu \mathrm{M}$ copper sulfate significantly decreased to 58.0 and $28.1 \%$, respectively, when compared with the control cells. Thus, $250 \mu \mathrm{M} \mathrm{CuSO}_{4}$ was determined to be the optimal subcytotoxic concentration used in this study.

Proliferation of U87-MG cells exposed to copper sulfate. To assess the effect of copper on the proliferation of U87-MG cells, we determined the cell activity of dehydrogenase enzymes by MTT assay at 1, 2, 3 and 4 days after exposure. For each condition, it was assumed that, on day 1, the proliferation index was 1 . Cell proliferation curves for the different conditions during exposure are shown in Fig. 2. Cells cultured in $\alpha$-MEM and control cells exhibited approximately the same proliferation rate, showing an increase in activity of dehydrogenase enzymes from 1- (day 1) to 2.37- and 1.93-fold (day 4), respectively, while cells exposed to 250 or $500 \mu \mathrm{M}$ copper

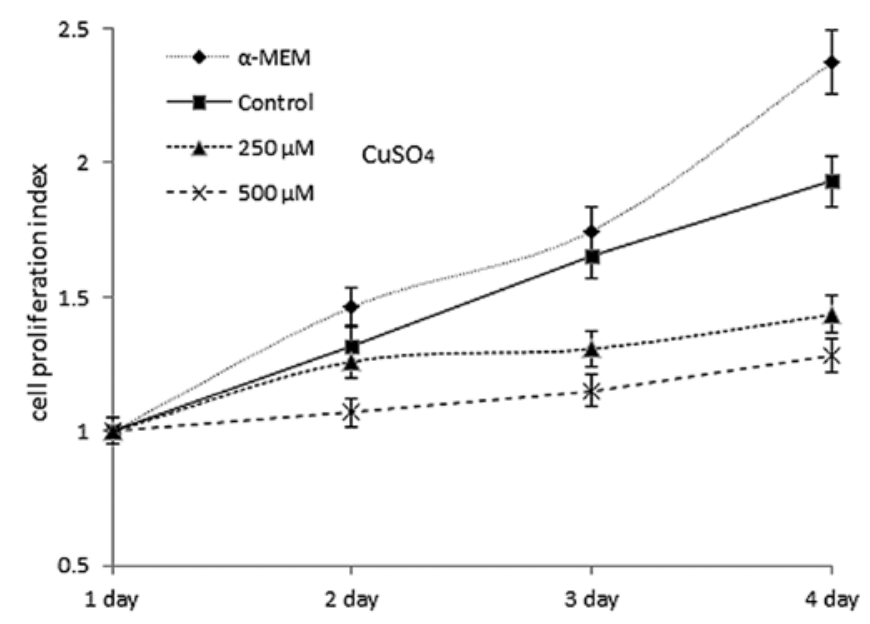

Figure 2. Cell proliferation curves of the U87-MG cells exposed to 250 and $500 \mu \mathrm{M}$ copper sulfate. Cells cultured in whole medium ( $\alpha$-MEM) and control cells exhibited approximately the same proliferation rate during the 4 days after stress. At the last day of exposure, the 250 or $500 \mu \mathrm{M}$ group showed a dramatic decrease in cell proliferation when compared with the control group. ${ }^{*} \mathrm{P}<0.05$ when compared with control.

sulfate only had an increase in proliferation from 1- (day 1) to 1.43 - and 1.28 -fold on day 4 , respectively.

Alterations in cell morphology and senescence-associated $\beta$-galactosidase activity in U87-MG cells treated with copper sulfate. The main morphological cell alterations observed in cellular senescence include an increase in the cell surface and a change from a small spindle-fusiform into a large flat spread. Alterations in the cell morphological features were noted in the U87-MG cells exposed to 250 or $500 \mu \mathrm{M}$ copper sulfate (Fig. 3A), including an enlarged cell surface and stellate outline with thin extensions. Cells incubated with $500 \mu \mathrm{M}$ copper sulfate had a lower cell density when compared with the cells cultured with $\alpha$-MEM, $250 \mu \mathrm{M}$ copper sulfate and the control cells (Fig. 3A), similarly to the results of the cell viability. SA $\beta$-gal staining is commonly used to provide evidence of cell senescence and whose activity increases with the process of aging. We compared the difference in $\beta$-gal activity among the $\alpha$-MEM-treated, the control, and the cells exposed to 250 and $500 \mu \mathrm{M}$ copper sulfate. No significant difference was detected between the $\alpha$-MEM and control group ( $\mathrm{P}=0.11)$. In contrast, the percentage of SA $\beta$-gal positive-stained cells increased significantly to $20(\mathrm{P}<0.05)$ and $27 \%(\mathrm{P}<0.05)$ following exposure to 250 and $500 \mu \mathrm{M}$ copper sulfate, respectively, when compared with the control group.

Senescence-associated gene expression in the U87-MG cell line exposed to copper sulfate. Alteration in the expression levels of several senescence-associated genes is a typical feature of senescence. The genes encoding apolipoprotein $\mathbf{J}$ (ApoJ), transforming growth factor $\beta 1$ (TGF- $\beta 1$ ), cyclindependent kinase inhibitor $1 \mathrm{~A}$ (p21), cyclin-dependent kinase inhibitor 2A (p16), insulin growth factor binding protein 3 (IGFBP3) and B lymphoma Mo-MLV insertion region-1 (Bmi-1) were detected by real-time PCR. Transcript levels of these genes were quantified $72 \mathrm{~h}$ after cell exposure to copper sulfate. We mainly focused on the difference between the 
A

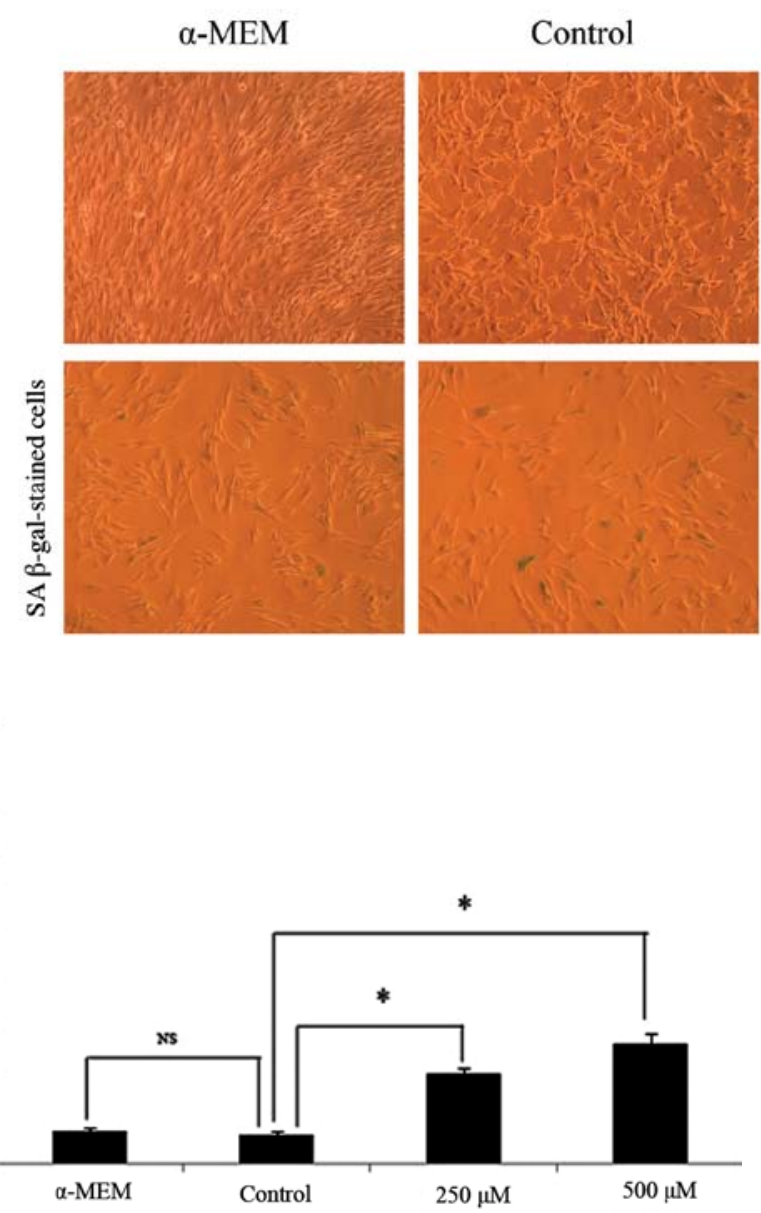

Figure 3. Changes in cell morphology and senescence-associated $\beta$-galactosidase activity in U87-MG cells following exposure to 250 or $500 \mu \mathrm{M}$ copper sulfate. (A) U87-MG cells exposed to 250 or $500 \mu \mathrm{M} \mathrm{CuSO}_{4}$ presented an enlarged cellular volume and altered shape, resembling the typical senescent phenotype. (B) The percentage of SA $\beta$-gal-positive stained cells increased to 20 and $27 \%$ when exposed to 250 and $500 \mu \mathrm{M} \mathrm{CuSO}_{4}$, respectively, compared with the control cells $(6 \%)$. ${ }^{*} \mathrm{P}<0.05$ when compared with the control.

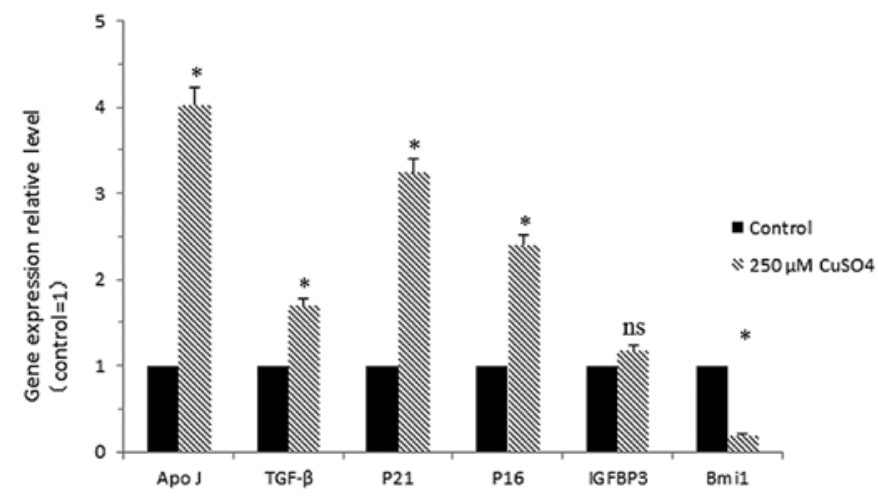

Figure 4. Relative mRNA levels of several senescence-associated genes by real-time PCR. Cells exposed to $250 \mu \mathrm{M} \mathrm{CuSO}_{4}$ showed statistically significant overexpression of ApoJ, TGF- $\beta 1$, p21 and p16 (4.0-, 1.7-, 3.2- and 2.4-fold, respectively) but a marked decrease in Bmi-1 (0.2-fold) when compared with the control cells. A non-significant increase in IGFBP3 mRNA expression (1.2-fold) was also observed when compared with the control cells. ${ }^{*} \mathrm{P}<0.05$ when compared with the control. ns, not significant.

control and the cells exposed to $250 \mu \mathrm{M} \mathrm{CuSO}_{4}$. Cells treated with $250 \mu \mathrm{M} \mathrm{CuSO}_{4}$ exhibited a statistically significant diffe-

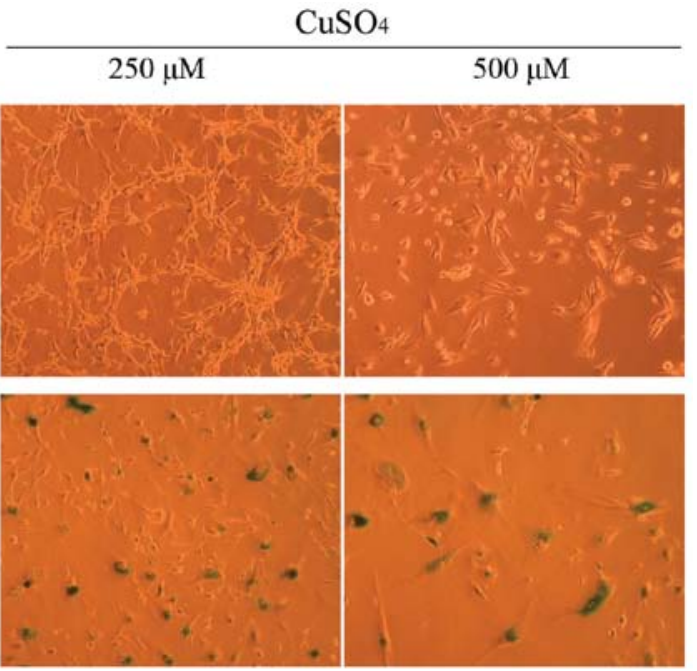

rence in mRNA levels of the senescence-associated genes ApoJ, TGF- $\beta 1$, p21 and p16 (4.0-, 1.7-, 3.2- and 2.4-fold, respectively) but a marked decrease in Bmi-1 (0.2-fold) when compared with the control cells. A non-significant increase in IGFBP3 mRNA expression (1.2-fold) was also observed (Fig. 4).

Western blot analysis of U87-MG cells exposed to copper sulfate. In order to analyze the mechanism of U87-MG senescence induced by copper sulfate, we assessed the protein levels of several senescence-associated genes, including Bmi-1, p16 and $\mathrm{p} 21$, by western blot analysis. The variation in the protein levels is shown in Fig. 5A, and the relative densitometric data were plotted (Fig. 5B). The intracellular level of actin did not have a statistically significant difference between the cells exposed to $250 \mu \mathrm{M} \mathrm{CuSO}_{4}$ and the control cells. However, the $250 \mu \mathrm{M} \mathrm{CuSO}_{4}$-treated cells showed increased protein levels of p21 and p16, but a decreased level of Bmi-1, when compared with the control cells.

\section{Discussion}

In the present study, we demonstrated that appropriate doses of copper sulfate induced the U87-MG cell line into a senescent state. High doses $(\geq 500 \mu \mathrm{M})$ of copper sulfate may be toxic to cells and cause a dramatic decrease in cell viability. Like many other oxidative agents, a subcytotoxic amount $(250 \mu \mathrm{M}$ in this study) of copper sulfate induced changes in cell structure and gene expression pattern which are specifically noted in cell aging, but do not significantly affect cell viability. In the present investigation, cell proliferation was found substantially reduced during the 4 days after treatment with $250 \mu \mathrm{M}$ of $\mathrm{CuSO}_{4}$, when compared with the control cells. Then, we choose $250 \mu \mathrm{M}$ as the most appropriate subcytotoxic dose employed thereafter to research copper-induced glioblastoma senescence.

Copper is an essential metal that functions as a transition element in many physiological activities, but it is also toxic to cells when intracellularly overloaded. Since copper contributes to the production of an excess of damaging oxidant radicals, similar to other oxidant agents, copper also induces normal cells into a premature senescent state (17). Data collected from in vitro experiments and cell culture studies prove that copper 
A

Control $\quad 250 \mu \mathrm{M}$

$\mathrm{CuSO}_{4}$
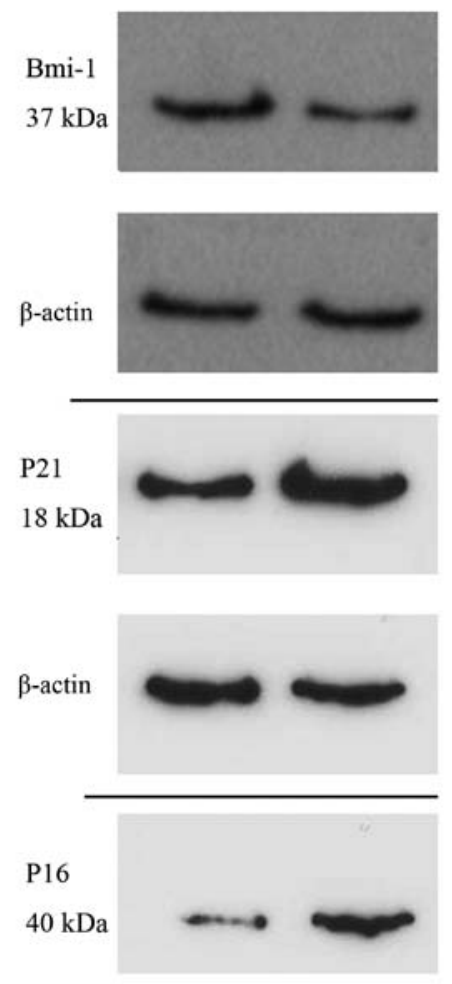

$\beta$-actin
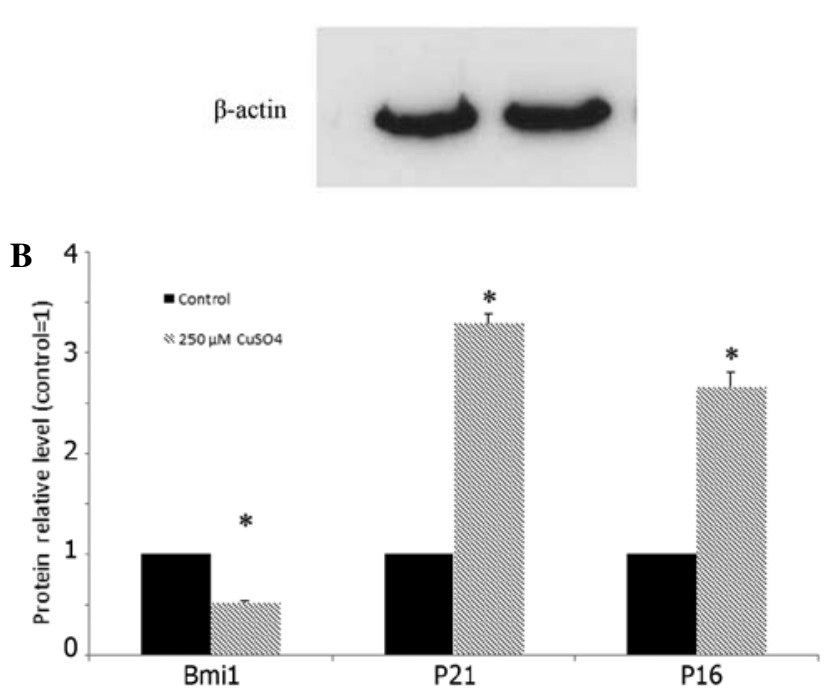

Figure 5. Western blot analysis of p21, p16 and Bmi-1 protein levels. (A) Representative blots indicating the levels of the different proteins. Actin was used as a loading control. (B) Results of the bands were quantified by ImagineJ. CuSO4-treated cells $(250 \mu \mathrm{M})$ showed increased protein levels of p21 and p16, but a decreased level of Bmi-1, when compared with the control cells. ${ }^{*} \mathrm{P}<0.05$ when compared with the control cells.

has the capacity to initiate oxidative damage and interfere with important cellular events (14).

Glioblastoma is one of the most aggressive brain tumors, driven by tumor stem cells as confirmed by stem cell research (20-22). To some extent, many features of these tumors are similar to normal stem cells, such as self-renewal ability, unlimited proliferation, and capability for differentiation. Therefore, we assumed that certain key genes and pathways which regulate stem cell proliferation and maintenance may also be fundamental to glioblastoma anti-senescence. Thus, we focused on the alteration of the $\mathrm{PcG}$ gene Bmi-1 in ionic copper-exposed glioblastoma cells. Since the main regulators of cell cycle progression through G1 phase are heterodimers, a cyclin-dependent kinases (10), the overexpression of CDK inhibitor p16 and p21 may function as biomarkers in replicative senescence. In order to confirm the glioblastoma cell senescence state, we also assessed the expression of other typical senescence-associated genes and proteins, including Apo J, TGF- $\beta$, p16, p21 and IGFBP3.

B lymphoma Mo-MLV insertion region-1 (Bmi-1), is a proto-oncogene, located on chromosome 10p11.23. It encodes a 324-amino acid nuclear protein which modifies the process of self-renewal in many types of stem cells (23-27). Previous reports have confirmed that the polycomb factor Bmi-1 inhibits cell cycle inhibitors p16, p19 and p21, promoting neuron stem cell (NSC) self-renewal. With increasing age and NSC passage, Bmi-1 enhancement of NSC self-renewal is significantly increased $(23,24,27)$. Some studies have shown that the NSCs markedly expand and demonstrate aggressive proliferation when Bmi-1 is overexpressed. Bmi-1 was found to sustain human glioblastoma self-renewal, and high expression in $\mathrm{CD}_{133^{+}}$tumor-initiating cells has been confirmed (28).

Collectively, the results showed that Bmi-1 was downregulated in copper-induced senescent U87-MG cells, at both the gene expression and protein level. Since Bmi-1 is considered to be a functional gene required for tumor cell growth (28-31), we hypothesized that the copper-induced glioblastoma cell aging occurs through the downregulation of Bmi-1. Yet, the detailed mechanism of how ionic copper downregulates Bmi-1 gene expression remains unclear.

We showed that a subcytotoxic dose of copper sulfate is able to induce senescence in the U87-MG glioblastoma cell line. The adaptative conditions of senescence were also observed, such as limitation of proliferation, enhanced SA $\beta$-gal activity, and alteration in expression of related genes. In the present study, we investigated the primary molecular mechanisms of copper-induced senescence in glioblastoma cells. By investigating the process of senescence of glioblastoma cells induced by ionic copper, we offer a new vision of how ionic metals affect tumor growth and proliferation. We also found that downregulation of Bmi-1 is a key mechanism of senescence in glioblastoma. Further research will be undertaken to explore the detailed mechanism of how ionic copper regulates senescence-associated genes in glioblastoma cells. Thus, efficient novel therapeutic strategies may be developed.

\section{Acknowledgements}

The present study was supported by the Program for New Century Excellent Talents in the University (no. NECT-060611), the National Science Foundation of China (nos. 81071008 and 81171177), the 211 Project-phase III of Zhengzhou University, the Basic and Clinical Research of Stem Cells, the Excellent Youth Foundation of Henan Scientific Committee (no. 114100510005), the Young Excellent Teachers in University Funded Projects of Henan Province, the Bureau of Science and Technology Development Project from Henan Province (no. 200902310250). 


\section{References}

1. Louis DN, Ohgaki H, Wiestler OD, et al: The 2007 WHO classification of tumours of the central nervous system. Acta Neuropathol 114: 97-109, 2007.

2. Ohgaki H, Dessen P, Jourde B, et al: Genetic pathways to glioblastoma: a population-based study. Cancer Res 64: 6892-6899, 2004.

3. Stupp R, Mason WP, van den Bent MJ, et al: Radiotherapy plus concomitant and adjuvant temozolomide for glioblastoma. $\mathrm{N}$ Engl J Med 352: 987-996, 2005.

4. Stupp R, Hegi ME, Mason WP, et al: Effects of radiotherapy with concomitant and adjuvant temozolomide versus radiotherapy alone on survival in glioblastoma in a randomised phase III study: 5-year analysis of the EORTC-NCIC trial. Lancet Oncol 10: 459-466, 2009.

5. Stupp R, Hegi ME, Gilbert MR and Chakravarti A: Chemoradiotherapy in malignant glioma: standard of care and future directions. J Clin Oncol 25: 4127-4136, 2007.

6. Ohgaki $\mathrm{H}$ and Kleihues P: Population-based studies on incidence, survival rates, and genetic alterations in astrocytic and oligodendroglial gliomas. J Neuropathol Exp Neurol 64: 479-489, 2005.

7. Bruggeman SW, Hulsman D, Tanger E, et al: Bmi-1 controls tumor development in an Ink4a/Arf-independent manner in a mouse model for glioma. Cancer Cell 12: 328-341, 2007.

8. Cancer Genome Atlas Research Network: Comprehensive genomic characterization defines human glioblastoma genes and core pathways. Nature 455: 1061-1068, 2008.

9. Ohgaki $\mathrm{H}$ and Kleihues P: Genetic alterations and signaling pathways in the evolution of gliomas. Cancer Sci 100: 2235-2241, 2009.

10. Hwang ES, Yoon G and Kang HT: A comparative analysis of the cell biology of senescence and aging. Cell Mol Life Sci 66: 2503-2524, 2009.

11. Nakahara Y, Shiraishi T, Okamoto H, et al: Detrended fluctuation analysis of genome-wide copy number profiles of glioblastomas using array-based comparative genomic hybridization. Neuro Oncol 6: 281-289, 2004.

12. Gupta A and Lutsenko S: Human copper transporters: mechanism, role in human diseases and therapeutic potential. Future Med Chem 1: 1125-1142, 2009.

13. Valko M, Morris H and Cronin MT: Metals, toxicity and oxidative stress. Curr Med Chem 12: 1161-1208, 2005.

14. Gaetke LM and Chow CK: Copper toxicity, oxidative stress, and antioxidant nutrients. Toxicology 189: 147-163, 2003.

15. Barnham KJ and Bush AI: Metals in Alzheimer's and Parkinson's diseases. Curr Opin Chem Biol 12: 222-228, 2008.
16. Brewer GJ: Risks of copper and iron toxicity during aging in humans. Chem Res Toxicol 23: 319-326, 2010.

17. Matos L, Gouveia A and Almeida H: Copper ability to induce premature senescence in human fibroblasts. Age 34: 783-794, 2012.

18. Dimri GP, Lee X, Basile G, et al: A biomarker that identifies senescent human cells in culture and in aging skin in vivo. Proc Natl Acad Sci USA 92: 9363-9367, 1995.

19. Bradford MM: A rapid and sensitive method for the quantitation of microgram quantities of protein utilizing the principle of protein-dye binding. Anal Biochem 72: 248-254, 1976.

20. Galli R, Binda E, Orfanelli U, et al: Isolation and characterization of tumorigenic, stem-like neural precursors from human glioblastoma. Cancer Res 64: 7011-7021, 2004.

21. Hemmati HD, Nakano I, Lazareff JA, et al: Cancerous stem cells can arise from pediatric brain tumors. Proc Natl Acad Sci USA 100: 15178-15183, 2003.

22. Singh SK, Hawkins C, Clarke ID, et al: Identification of human brain tumour initiating cells. Nature 432: 396-401, 2004.

23. Simon JA and Tamkun JW: Programming off and on states in chromatin: mechanisms of Polycomb and trithorax group complexes. Curr Opin Genet Dev 12: 210-218, 2002.

24. Orlando V: Polycomb, epigenomes, and control of cell identity. Cell 112: 599-606, 2003.

25. Lessard J, Baban S and Sauvageau G: Stage-specific expression of polycomb group genes in human bone marrow cells. Blood 91: 1216-1224, 1998.

26. Park IK, Qian D, Kiel M, et al: Bmi-1 is required for maintenance of adult self-renewing haematopoietic stem cells. Nature 423: 302-305, 2003.

27. Molofsky AV, Pardal R, Iwashita T, Park IK, Clarke MF and Morrison SJ: Bmi-1 dependence distinguishes neural stem cell self-renewal from progenitor proliferation. Nature 425: 962-967, 2003.

28. Abdouh M, Facchino S, Chatoo W, Balasingam V, Ferreira J and Bernier G: Bmi-1 sustains human glioblastoma multiforme stem cell renewal. J Neurosci 29: 8884-8896, 2009.

29. Vonlanthen S, Heighway J, Altermatt HJ, et al: The bmi-1 oncoprotein is differentially expressed in non-small cell lung cancer and correlates with INK4A-ARF locus expression. Br J Cancer 84: 1372-1376, 2001.

30. Kim JH, Yoon SY, Jeong SH, et al: Overexpression of Bmi-1 oncoprotein correlates with axillary lymph node metastases in invasive ductal breast cancer. Breast 13: 383-388, 2004.

31. Leung C, Lingbeek M, Shakhova O, et al: Bmi-1 is essential for cerebellar development and is overexpressed in human medulloblastomas. Nature 428: 337-341, 2004. 